Olha Zinchenko ${ }^{1}$, Viktor Vyshnivskyi ${ }^{1}$, Yuliia Berezovska ${ }^{1}$, Peter Sedlaček ${ }^{2}$

${ }^{1}$ State University of Telecommunications, Kyiv, Ukraine

${ }^{2}$ University of Žilina, Žilina, Slovakia

\title{
EFFICIENCY OF COMPUTER NETWORKS WITH SDN IN THE CONDITIONS OF INCOMPLETE INFORMATION ON RELIABILITY
}

\begin{abstract}
The paper analyzes the effectiveness of computer networks with SDN in conditions of incomplete reliability information. In order to ensure the specified indicators of the reliability of the computer network, it is recommended to use their guaranteed estimates. To increase the level of security of information systems and introduce the concept of time reserve in the process of packet transmission, it is necessary to separate the functions of traffic transmission from management functions. This is the basic principle of SDN. When using SDN technology in computer networks, it is possible to enter a time reserve when transmitting messages. This makes it possible to more accurately determine the reliability. The evaluation of the data transmission system of the computer network takes into account the possibility of entering a time reserve and obtained the basic calculated ratios for reliability indicators in terms of incomplete information about their distribution laws. A priori information is limited by knowledge of the first initial moments of mathematical expectation and variance. These results are a justification for the structure of computer networks that are designed or upgraded. You can also use this information to build highly reliable networks or technical facilities that exist in a single implementation.
\end{abstract}

Keywords: information system; functional stability; software-defined networking; network; data transfer; limited a priori information; security performance.

\section{Introduction}

The operation of computer networks $(\mathrm{CN})$, designed to automate management, is in constant interaction with external influences. Information conflicts that occur as a result of such interaction cause the destruction of information resources, disruption of regular information processes, and as a consequence of the failure of system and application functions. All this determines the presence of mechanisms in the $\mathrm{CN}$, which should ensure their reliability.

A difficult scientific and practical task at present is the assessment of reliability indicators needed to compare different design options. An even more difficult task is to find the best option that achieves optimal reliability with certain limitations [11].

Modern CMs require the implementation of management tools using protocols that do not depend on services and, in turn, are provided by different operators and / or pro-providers throughout the network, regardless of the types of technical systems used in it. Creating systems that are a priori focused on working in conditions of incomplete or fuzzy output, uncertainty of external fluctuations and the working environment, requires the use of innovative approaches to management using new methods and technologies. It is obvious that in the presence of different types of uncertainty, a high level of autonomy, adaptability and reliability of $\mathrm{CN}$ should be ensured by increasing their capabilities based on the processing of special information. One of the main selection criteria should be the required quality of operation of the control system in conditions of uncertainty with the random nature of external fluctuations, which include unforeseen changes in their own performance, environmental parameters, goals and more.

The efficiency of the $\mathrm{CN}$ is largely determined by time delays in data transmission between network users. Minimization of delay in $\mathrm{CN}$ with homogeneous traffic is provided at the design stage using mathematical models of mass service with a homogeneous flow of applications.

Currently, multiservice networks are becoming widespread, the characteristic feature of which is the heterogeneity of traffic $[1,2]$. Heterogeneity of traffic is the transmission of information network packets of several types (video and audio packages, full packets, text packets, etc.), which are subject to different requirements [3]. These requirements will be formulated in the form of restrictions on the delivery time of packages of different types. In this case, the restrictions can be of two types: probabilistic in the form of the allowable probability of exceeding the established time delay limits of packets in the information network and average in the form of a limit on the average delay time. This limit can be taken into account through the use of special traffic management methods. Solving this problem requires the use of models with a heterogeneous flow of applications that allow you to analyze the properties of priority data transmission systems and formulate recommendations for the design of priority networks.

Therefore, to ensure the reliability of the $\mathrm{CN}$, it is proposed to use software-configured networks (SDN) [4, 5]. When using software-configured networks (SDN), it is possible to introduce the concept of time reserve into the packet transmission process. That is, the system redirects a packet that was not transmitted on another trajectory. However, if the delivery time of this packet does not exceed the allowable delay time, it will be considered that the communication channel failed.

The role of reliability indicators, which are interpreted as characteristics of probabilistic mathematical models of objects, is performed by statistical estimates of the corresponding probabilistic characteristics. When evaluating these indicators, the necessary initial data for a priori probabilistic calculations are often missing, and statistical evaluation is complicated by a small amount of testing, which can determine only estimates of moments of random 
variables that determine the process of operation (mathematical expectations and variances of failure time, recovery time, backup time etc).

Therefore, in this work the problem of development of an analytical method of the decision of extreme problems of definition of bilateral estimations of functionalities which are included in the basic indicators of reliability of $\mathrm{CN}$ with a time reserve is solved. It is necessary to construct two-sided estimates of these indicators for $\mathrm{CN}$ with SDN with time redundancy at known moments of distribution of initial random variables which define random processes which are investigated. In solving this problem, the limit values of the functionals that characterize the validity of such systems are used.

The obtained results are a substantiation of the structure of computer networks that are designed or modernized. You can also use this information to build highly reliable networks or technical facilities that exist in a single implementation.

\section{Results of the research}

The ability of IT administrators to monitor the operation of the entire information network using a socalled software controller, which is separate from the switch and the level of traffic, is the basis of SDN management. Using a single control point, which is universally used in the virtual network architecture, allows administrators to take control of all switch networks [7]. This approach meets modern requirements for $\mathrm{CN}$.

The network device of the control layer is separated from the data transmission layer and is logically centralized in the SDN-controller, which provides a single abstract representation of the entire network and its state. It can be deployed as a cluster to ensure high availability and scalability, as well as to provide interoperability between traffic controllers between different CN. Centralized application of increased productivity, reduction of delays leads to more efficient interaction between users and applications in both corporate networks and data center networks. The number of network devices will inevitably increase over time and a simple way to manage them, which is SDN certainly has advantages $[9,10]$. This technology is a new approach to the design, construction and operation of $\mathrm{CN}$, which focuses on providing business flexibility due to the effective connection of users to applications. It is a transition from managing network generating devices to managing entire networks.

The network can respond more quickly to changing business needs. The SDN controller supports an open programming interface (API), a number of built-in features, including network virtualization, security, traffic management, and authorization and authentication mechanisms to control access to the controller's integrated tools and external SDN applications, allowing external programming. thus an environment for automation, management, and scaling functionality for future applications $[4,10]$. The implementation of this concept greatly simplifies the operation of the network and its configuration and allows it to be used in large companies and small and medium-sized businesses.

Therefore, it can be argued that during the construction of $\mathrm{CN}$ it is advisable to implement a solution to the problem in accordance with SDN technology. This will allow companies and telecom operators to gain independent control over the entire network and greatly simplify their operation. Last but not least, greatly simplified network configuration. Administrators will not need to enter hundreds of new lines of code separately for different switches or routers. It is possible to quickly change, in real time, the characteristics of the network. Accordingly, the time to initiate new applications and services is significantly reduced, which in turn will maintain the reliability of the $\mathrm{CN}$.

Let's consider features of an estimation of efficiency of $\mathrm{CN}$ as one of cases on probability of operability of the transmission channel. To do this, consider the process of transmitting information in the $\mathrm{CM}$ of continuous use with time redundancy, which consists of two elements: the transmission channel and the time reserve. Performance control will be considered ideal (complete, continuous and reliable). Formulas for the main indicators of the reliability of such a system with complete source information are given in [6].

Consider the cases when the type of distribution function $F_{\mathrm{B}}(t)$ of the recovery time of the transmission channel $t_{\mathrm{B}}$ of the distribution function $D(t)$ of the value of the reserve time $t_{\mathrm{A}}$ is not set, and only their first two initial moments are known. The task is to find bilateral assessments (lower and upper limits) of the main indicators of the reliability of the system for these cases.

It is worth noting that bilateral estimates for reliability indicators are obtained under the assumption that the average operating time of the object on the failure of the transmission channel is much longer than the average recovery time. This condition is fulfilled in engineering practice for $\mathrm{CN}$.

1. Let us know only the first two initial moments of the distribution function $F_{\mathrm{B}}(t)$

$$
\begin{gathered}
s_{1}=t_{\mathrm{B}}=\int_{0}^{\infty} x d F_{\mathrm{B}}(x), \\
s_{2}=\int_{0}^{\infty} x^{2} d F_{\mathrm{B}}(x) ; s_{1} \leq t_{\mathrm{A}}<\frac{s_{1}}{s_{2}},
\end{gathered}
$$

where $s_{1}^{2}<s_{2}$. The class of distribution functions that satisfy such a constraint is denoted by $K_{2}$.

For this case, in [6], bilateral estimates of the functionalities characterizing the reliability of the system are obtained. Taking into account these estimates for the reliability indicators obtained for the case of complete a priori information, the calculated ratios for the lower and upper limits of these indicators are given below. In the formulas below $\underline{t}_{\mathrm{H}}$ - the average operating time of the transmission channel to failure:

$$
\underline{t}_{\mathrm{H}}=\int_{0}^{\infty}[1-F(t)] d t .
$$

Let the reserve time be a non-random variable $t_{\text {д }}=$ const. For this case in [6] the exact lower ones are given $I_{1}\left(F_{\mathrm{B}}\right)$ and upper $I_{1}\left(F_{\mathrm{B}}\right)$ functional assessment $I_{1}\left(F_{\mathrm{B}}\right)=$ $F_{\text {в }}\left(t_{\text {д }}\right)$.

The probability of trouble-free operation of the system $P\left(t, t_{\mathrm{A}}\right)$ depending on the delay time of the 
information packet in the transmission channel:

$$
\begin{aligned}
& P\left(t, t_{\text {म }}\right) \approx \exp \left[-\frac{\left(t-t_{\text {म }}\right) q^{*}}{\underline{t}_{\mathrm{H}}}\right] \approx \\
& \approx\left\{\begin{array}{l}
\exp \left(-\frac{t-t_{\text {Д }}}{t_{\mathrm{H}}}\right), \quad 0<t_{\text {д }}<s_{1} ; \\
\exp \left[-\frac{\left(t-t_{\text {Д }}\right) s_{1}}{t_{\mathrm{H}} t_{\text {Д }}}\right], \quad s_{1} \leq t_{\text {д }}<\frac{s_{1}}{s_{2}} ; \\
\exp \left[-\frac{\left(t-t_{\text {Д }}\right)\left(s_{2}-s_{1}^{2}\right)}{t_{\mathrm{H}}\left(s_{2}-2 s_{1} t_{\text {म }}+t_{\text {म }}^{2}\right)}\right], t_{\text {Д }} \geq \frac{s_{2}}{s_{1}} ;
\end{array}\right. \\
& P\left(t, t_{\text {म }}\right) \approx \exp \left[-\frac{\left(t-t_{\text {म }}\right) q_{*}}{\underline{t}_{\mathrm{H}}}\right] \approx \\
& \approx\left\{\begin{array}{lr}
\exp \left[-\frac{\left(t-t_{\text {म }}\right)\left(s_{1}-t_{\text {A }}\right)^{2}}{\underline{t}_{\mathrm{H}}\left(s_{2}-2 s_{1} t_{\text {म }}+t_{\text {म }}^{2}\right)}\right], & 0<t_{\text {Д }}<s_{1} ; \\
1, & s_{1} \leq t_{\text {Д }}<\frac{s_{2}}{s_{1}} ; \\
1, & t_{\text {Д }} \geq \frac{s_{2}}{s_{1}} .
\end{array}\right.
\end{aligned}
$$

In formulas (4) and (5) the restriction is accepted: $t-t_{\text {д }} \geq 0$.

Idle rate $K_{\Pi}\left(t_{д}\right)$. In the formula for $K_{\Pi}\left(t_{д}\right)$ includes functionality:

$$
I_{4}\left(F_{\mathrm{B}}\right)=M\left[\min \left(t_{\mathrm{B}}, t_{\mathrm{A}}\right)\right]=\int_{0}^{t_{\mathrm{A}}}\left[1-F_{\mathrm{B}}(t)\right] d t,
$$

for which the bottom is obtained $I_{4}\left(F_{\mathrm{B}}\right)$ and top $I_{4}\left(F_{\mathrm{B}}\right)$ evaluation.

Enter the notation:

$$
\mathrm{M}_{*}=I_{4}\left(F_{\mathrm{B}}\right), \mathrm{M}^{*}=I_{4}\left(F_{\mathrm{B}}\right) .
$$

Then the limit values of the functional $I_{4}\left(F_{\mathrm{B}}\right)$, taking into account the entered notations will be two-way estimates of the coefficient of readiness of the transmission channel:

$$
\begin{gathered}
K_{\Pi}\left(t_{\text {д }}\right)=1-\frac{\underline{t}_{\mathrm{H}}+\mathrm{M}_{*}}{\underline{t}_{\mathrm{H}}+s_{1}}= \\
= \begin{cases}1-\frac{\underline{t}_{\mathrm{H}}+t_{\text {म }} \frac{s_{1}^{2}}{s_{2}}}{\underline{t}_{\mathrm{H}}+s_{1}}, & t_{\text {д }}<\frac{s_{2}}{2 s_{1}} ; \\
1-\left(\underline{t}_{\mathrm{H}}+s_{1}\right)^{-1}\left[\underline{t}_{\mathrm{H}}+0,5 \times\right. & \\
\left.\times\left(s_{1}+t_{\text {д }}-\sqrt{t_{\text {म }}^{2}-2 s_{1} t_{\text {д }}+s_{2}}\right)\right], & t_{\text {д }} \geq \frac{s_{2}}{2 s_{1}} ;\end{cases}
\end{gathered}
$$

Table 1 - Estimates of reliability indicators

\begin{tabular}{|c|c|c|c|}
\hline Indicator & Time reserve $t_{\text {д1 }}=10 \mathrm{~ms}$ & Time reserve $t_{\text {д2 }}=50 \mathrm{~ms}$ & Time reserve $t_{\text {д3 }}=150 \mathrm{~ms}$ \\
\hline$P\left(t, t_{\text {म }}\right)$ & 0,99972 & 0,999996 & 0,9999996 \\
\hline$K_{\mathrm{\Gamma}}\left(t_{\text {म }}\right)$ & 0,999999991 & 0,999999999 & 1 \\
\hline
\end{tabular}

Graphs of the lower limit of the probability of failure-free operation for different data traffic or data inherent in their time reserve values are presented in Fig. 1. The analysis of the results shown in Table 1 and the graphs in Fig. 1 shows that taking into account the time reserve for the data transmission system allows to

$$
\begin{gathered}
K_{\Pi}\left(t_{\text {म }}\right)=1-\frac{\underline{t}_{\mathrm{H}}+\mathrm{M}^{*}}{\underline{t}_{\mathrm{H}}+s_{1}}= \\
= \begin{cases}\frac{\underline{t}_{\mathrm{H}}+t_{\text {म }}}{\underline{t}_{\mathrm{H}}+s_{1}}, & t_{\text {म }}<s_{1} ; \\
0, & t_{\text {д }} \geq s_{1} .\end{cases}
\end{gathered}
$$

For example, consider the $\mathrm{CN}$ of continuous use with time redundancy.

Requirements of mobile operators for the maximum allowable packet delay time for premium services not more than $50 \mathrm{~ms}$, and for standard services not more than $150 \mathrm{~ms}$. [8]. Thus, different data traffic will have different time reserve values, namely $10 \mathrm{~ms}, 50 \mathrm{~ms}$ and $150 \mathrm{~ms}$.

The studied $\mathrm{CN}$ will be characterized by the following data:

$$
\begin{gathered}
t_{\mathrm{H}}=10^{4} \mathrm{~s}, \mathrm{~s}_{1}=\underline{t}_{\mathrm{B}}=5 \mathrm{~ms}, \mathrm{~s}_{2}=26 \mathrm{~ms}, \\
t_{\text {д1 }}=10 \mathrm{~ms}, t_{\text {д2 }}=50 \mathrm{~ms}, t_{\text {д3 }}=150 \mathrm{~ms} .
\end{gathered}
$$

It is necessary to determine bilateral assessments of system reliability $P\left(t, t_{\text {д }}\right), K_{\Gamma}\left(t_{\text {д }}\right)$ for three time reserve values:

$$
\begin{gathered}
t_{\text {д1 }}=10 \mathrm{~ms}, t_{\text {д2 }}=50 \mathrm{~ms}, \\
t_{\text {д3 }}=150 \mathrm{~ms} .
\end{gathered}
$$

We will be interested in the upper limit of the probability of failure and the lower limits of the probability of failure and readiness.

Since $t_{\mathrm{A}} \geq \frac{s_{2}}{s_{1}}$ for three values of the time reserve, the formulas for reliability indicators will be as follows:

$$
\begin{gathered}
P\left(t, t_{\text {म }}\right) \approx \exp \left[-\frac{\left(t-t_{\text {म }}\right) q^{*}}{\underline{t}_{\mathrm{H}}}\right] \approx \\
\approx \exp \left[-\frac{\left(t-t_{\text {म }}\right)\left(s_{2}-s_{1}^{2}\right)}{t_{\mathrm{H}}\left(s_{2}-2 s_{1} t_{\mathrm{A}}+t_{\mathrm{A}}^{2}\right)}\right] ; \\
K_{\Pi}\left(t_{\text {म }}\right)=\frac{\underline{t}_{\mathrm{H}}+\mathrm{M}_{*}}{\underline{t}_{\mathrm{H}}+s_{1}}=\left(\underline{t}_{\mathrm{H}}+s_{1}\right)^{-1} \times \\
\times\left[\underline{t}_{\mathrm{H}}+0,5\left(s_{1}+t_{\text {म }}-\sqrt{t_{\text {म }}^{2}-2 s_{1} t_{\text {म }}+s_{2}}\right)\right] .
\end{gathered}
$$

The results of the calculation of bilateral assessments of the reliability of the system are shown in table 1 . objectively assess the reliability of the network information transmission channel in conditions of a priori uncertainty of data on random variables.

Increasing the backup time to ensure the maximum allowable packet delay time in the channel leads to an increase in the reliability of the studied systems. 


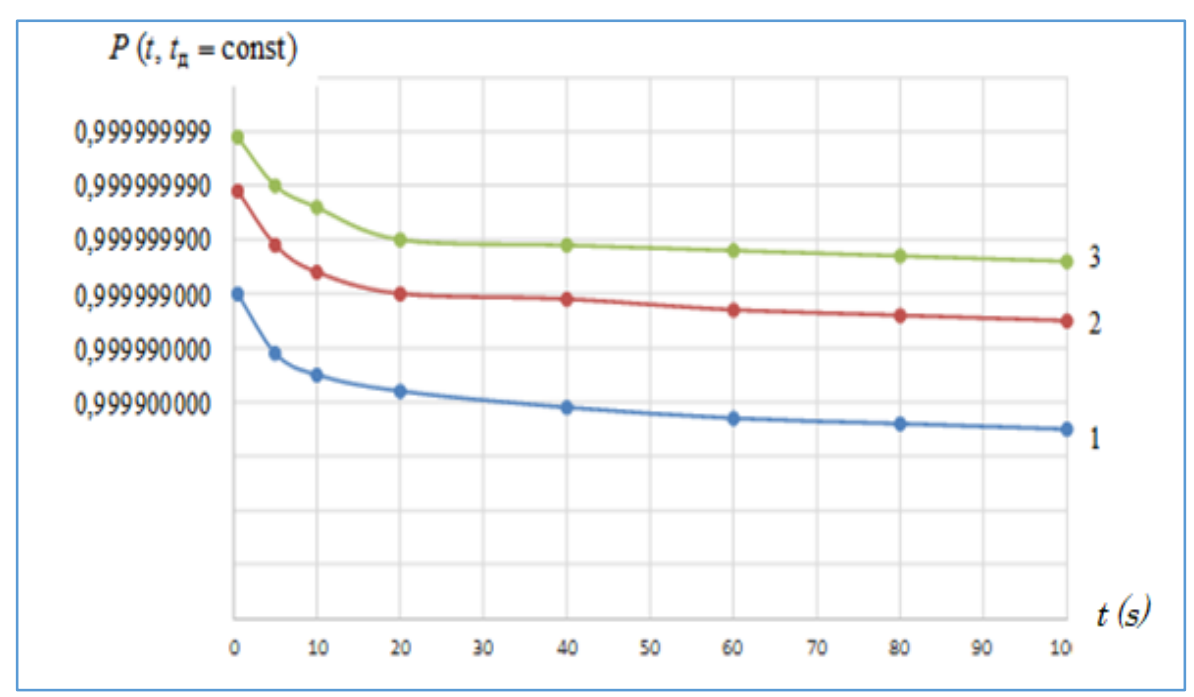

Fig. 1. The lower limit of the probability of failure $\left(1-t_{\text {д1 }}=10 m s, 2-t_{\text {д } 2}=50 m s, 3-t_{\text {д } 3}=150 m s\right)$

Thanks to the obtained guaranteed estimates of the upper limit of the probability of failure and the lower limit of the probability of failure-free operation and the coefficient of readiness, it is possible to realistically assess the quality of the CM.

\section{Analysis of the results allows us to draw the following conclusions}

The analysis conducted in the work showed that information conflicts in computer networks lead to failures. At the same time, modern computer networks operate in conditions of incomplete source information. Therefore, it is necessary to use measures to ensure a given level of reliability.

Based on the evaluation of linear and fractionallinear functionalities, the sets of calculation ratios are obtained to determine the guaranteed (largest and smallest) values of the main indicators of reliability of computer networks with a reserve. Thus, the scientific problem of development of the analytical method of the decision of an extreme problem of definition of bilateral estimations of the functionalities entering into the basic indicators of reliability of computer networks with a time reserve is solved in work. Bilateral estimates of reliability indicators of computer networks with time redundancy at the known first two points of random variables are constructed.

In solving this problem, the limit values of the functionalities that characterize the reliability of such systems are used.

The analysis of the obtained results showed that taking into account the time reserve for the data transmission system makes it possible to objectively assess the reliability of computer networks with time reserve in the conditions of a priori uncertainty of data on determining random variables.

The obtained results are a substantiation of the structure of computer networks, which are designed or modernized. You can also use this information to build highly reliable networks or technical facilities that exist in a single implementation.

\section{Acknowledgment}

The Slovak Research and Development Agency (Agentúra na Podporu Výskumu a Vývoja) supported this work under the contract no. APVV-18-0027 titled "New methods development for reliability analysis of complex system".

\section{REFERENCES}

1. Kulgin, M. (1999), Technology of corporate networks, Peter, St. Petersburg, 704 p.

2. Kulgin, M. (1998), "Introduction to the Traffic Management System", Journal of Network Solutions/LAN [Zhurnal setevykh resheniy/LAN], no. 11, pp. 25-28.

3. Hall, E. (1988), "Prioritization of traffic in IP networks", Networks and communication systems [Seti $i$ sistemy svyazi], No. 11 (33), P. 34-39.

4. Gaidur, G.I., Ilyin, O.O. and Serich, S.O. (2017), "Information technology for the implementation of the algorithm for the synthesis of the graph for assessing the criteria for mastering competencies", Svyazok [Zvyazok], No. 4, pp. 30-34.

5. Shalimov A.V. (2020), SDN\&NFV: Technologies SDN/OpenFlow, available at: http://lvk.cs.msu.su/ sveta/SDN_OpenFlow_basics_lecture1.pdf

6. Kredentser, B.P., Vyshnivsky, V.V., Zherdev, M.K., Mogilevich, D.I. and Stoykova, L.S. (2013), Assessing the reliability of redundant systems with limited source information [Otsinka nadiynosti rezervovanykh system pry obmezheniy vykhidniy informatsiyi], Phoenix, Kyiv, 335 p.

7. Gaidur, G.I. (2017), "Methods for determining the economic feasibility of maintaining an intelligent information system in conditions of a priori uncertainty", Modern information protection [Suchasnyy zakhyst informatsiyi], No. 4 (32), pp. 9-13.

8. Kuchuk, G.A. (2013), Information technologies for integrated data flow control in information and telecommunication networks of critical systems [Informatsiyni tekhnolohiyi upravlinnya intehral'nymy potokamy danykh $v$ informatsiynotelekomunikatsiynykh merezhakh system krytychnoho pryznachennya]: monograph, HUPS, Kharkiv, 264 p. 
9. Gnidenko, M.P., Vyshnivsky, V.V., Serykh, S.O., Zinchenko, O.V. and Prokopov, S.V. (2019), Convergent Network Infrastructure [Konverhentna merezhna infrastruktura]: Textbook, DUT, Kyiv, 182 p.

10. Gnidenko M.P., Vyshnivsky, V.V. and Ilyin O.O. (2019), Building SDN networks [Pobudova SDN merezh]: a textbook, DUT, Kyiv, $190 \mathrm{p}$.

11. Vasylenko V., Kuklov, V. and Grynkevych, G. (2016), "Analysis of SDN for wireless handover platform", Telecommunications and Computer Science (TCSET): 13 ${ }^{\text {th }}$ International Conference on Modern Problems of Radio Engineering, Lviv: 23-26 Feb. 2016, pp. 630-633, DOI: http://dx.doi.org/10.1109/TCSET.2016.7452136.

Received (Надійшла) 12.02.2021

Accepted for publication (Прийнята до друку) 09.04.2021

\section{ABOUT THE AUTHORS / ВІДOМOCTI ПРО АВTOPIB}

Зінченко Ольга Валеріївна - кандидат технічних наук, доцент, завідувач кафедри штучного інтелекту, Державний університет телекомунікацій, Київ, Україна;

Olha Zinchenko - Candidate of Technical Sciences, Associate Professor, Head of Department of Artificial Intelligence, State University of Telecommunications, Kyiv, Ukraine;

e-mail: Zinchenkoov@ gmail.com; ORCID ID: http://orcid.org/0000-0002-3973-7814.

Вишнівський Віктор Вікторович - доктор технічних наук, професор, завідувач кафедри комп'ютерних наук, Державний університет телекомунікацій, Київ, Україна;

Viktor Vyshnivskyi - Doctor of Technical Sciences, Professor, Head of Department of Computer Science, State University of Telecommunications, Kyiv, Ukraine;

e-mail: vish_vv@ukr.net; ORCID ID: http://orcid.org/0000-0003-1923-4344.

Березовська Юлія Володимирівна - асистент кафедри комп'ютерних наук, Державний університет телекомунікацій, Київ, Україна;

Yuliia Berezovska - Assistant of Department of Computer Science, State University of Telecommunications, Kyiv, Ukraine; e-mail: krasabereza@gmail.com; ORCID ID: https://orcid.org/0000-0002-9973-0497.

Седлачек Петер - аспірант, факультет управлінських наук та інформатики, Жилінський університет, Жиліна, Словаччина; Peter Sedlaček - postgraduate student, Faculty of Management Science and Informatics, University of Žilina, Žilina, Slovakia; e-mail: Peter.Sedlacek@fri.uniza.sk; ORCID ID: https://orcid.org/0000-0002-7481-6905.

\section{Ефективність функціонування комп'ютерних мереж із SDN в умовах неповноти інформації про надійність}

О. В. Зінченко, В. В. Вишнівський, Ю. В. Березовська, П. Седлачек

Анотація. В роботі проведено аналіз ефективності функціонування комп'ютерних мереж 3 SDN в умовах неповноти інформації про надійність. Для того, щоб забезпечити задані показники надійності комп'ютерної мережі пропонується використовувати їх гарантовані оцінки. Для підвищення рівня безпеки функціонування інформаційних систем та ввести в процес передачі пакетів поняття резерву часу необхідно відокремити функції передачі трафіку від функцій управління. В цьому і полягає основний принцип SDN. При використанні технології SDN в комп'ютерних мережах з'являється можливість введення резерву часу при передачі повідомлень. Це дає можливість більш точно визначити показники надійності. При оцінці системи передачі даних комп'ютерної мережі врахована можливість введення резерву часу та отримані основні розрахункові співвідношення для показників надійності в умовах неповної інформації про їх закони розподілу. Апріорна інформація обмежена знанням перших початкових моментів математичного сподівання та дисперсії. Дані результати являються обгрунтуванням структури комп'ютерних мереж, які проектуються або модернізуються. Також цю інформацію можна використати при побудові високонадійних мереж або технічних об'єктів, які існують в одиничному виконанні.

Ключові слова : інформаційна система; функціональна стійкість; програмно-кофігуровані мережі; мережа; передача даних; обмежена апріорна інформація; безпека функціонування.

\section{Эффективность функционирования компьютерных сетей с SDN в условиях неполноты информации о надежности \\ О. В. Зінченко, В. В. Вишневский, Ю. В. Березовская, П. Седлачек}

Аннотация. В работе проведен анализ эффективности функционирования компьютерных сетей SDN в условиях неполноты информации о надежности. Для того, чтобы обеспечить заданные показатели надежности компьютерной сети предлагается использовать их гарантированные оценки. Для повышения уровня безопасности функционирования информационных систем и ввести в процесс передачи пакетов понятие резерва времени необходимо отделить функции передачи трафика от функций управления. В этом и заключается основной принцип SDN. При использовании технологии SDN в компьютерных сетях появляется возможность ввода резерва времени при передаче сообщений. Это дает возможность более точно определить показатели надежности. При оценке системы передачи данных компьютерной сети учтена возможность ввода резерва времени и получены основные расчетные соотношения для показателей надежности в условиях неполной информации об их законах распределения. Априорная информация ограничена знанием первых начальных моментов математического ожидания и дисперсии. Данные результаты являются обоснованием структуры компьютерных сетей, проектируемых или модернизирующихся. Также эту информацию можно использовать при построении высоконадежных сетей или технических объектов, которые существуют в единичном исполнении.

Ключевые слова: информационная система; функциональная устойчивость; программно-кофигурируемые сети; сеть; передача данных; ограниченая априорная информация; безопасность функционирования. 